\title{
RANCANG BANGUN SISTEM PENGATURAN KECEPATAN MOTOR ARUS SEARAH MENGGUNAKAN METODE DUAL H-BRIDGE BERBASIS ARDUINO
}

\author{
Zuly Budiarso $^{1}$, Eddy Nurraharjo ${ }^{2}$, Hersatoto Listiyono ${ }^{3}$ \\ Program Studi Teknik Informatika, Fakultas Teknologi Informasi, Universitas Stikubank \\ e-mail: zulybudiarso@edu.unisbank.ac.id
}

\begin{abstract}
Abstrak
Komponen penggerak yang sering digunakan sebagai sumber gerakan dalam berbagai perlalatan listrik adalah motor arus searah. Dalam berbagai keperluan, besanya kecepatan putaran motor arus searah sangat diperlukan untuk menentukan kinerja sistem gerak.Untuk mengatur kecepatan motor arus searah dapat dilakukan dengan cara yaitu menambah potensial catu daya.

Dengan berkembangnya teknologi digital yang semakin pesat, menyebabkan teknologi sistem pengaturan juga mengalami perkembangan yang pesat pula. Sebuah sistem pengaturan tidak lagi menerapkan rangkaian elektronik sebagai alat pengendali. Arduino Mega 2560 merupakan salah satu jenis mikrokontroler yang sering digunakan dalam sistem kendali.

Sistem pengaturan kecepatan motor arus searah merupakan sebuah sistem pengaturan yang berfungsi mengatur kecepatan motor arus searah menggunakan perangkat lunak. Proses utama yang terjadi dalam sistem pengaturan kecepatan motor arus searah adalah mengatur kondisi pin-pin digital pada arduino yang akan dijadikan sebagai triger untuk memicu motor arus searah.

Sinyal dari arduino menjadi triger bagi sebuah modul driver motor dc yang berupa rangkaian elektronik yang bekerja dengan cara Dual H-Bridge. Modul terdiri dari 2 pasang masukan dan keluaran. Pin masukan berfungsi menerima sinyal dari arduino, sedangkan pin keluaran dihubungkan dengan 2 buah motor arus searah. Kecepatan motor tergantung frekuensi sinyal sinyal dari arduino, sedangkan frekuensi tergantung sketch program pada arduino.
\end{abstract}

Kata kunci : arduino, motor arus searah, dual H-Bridge

\section{PENDAHULUAN}

Motor Arus searah merupakan sebuah peralatan listrik yang sering digunakan dalam berbagai peralatan misal mobil-mobilan, robot, penggerak roda, penggerak lengan dan lainlain. Fungsi utama motor arus searah dalam setiap alat adalah sebagai sumber gerak bagi peraltan tersebut. Sebagai sumber gerak motor arus searah mempunyai beberapa kriteria diantaranya adalah kekutan torsi putar, kecepatan putar dan daya listrik yang dibutuhkan.

Kekuatan torsi dapat diatur berdasar jumlah lilitan pada kumparan, besarnya magnet permanen yang digunakan, ukuran badan magnet dan beberapa hal yang berhubungan dengan ukuran fisik dari motor arus searah. Catu daya yang dibutuhkan tergantung pada ukuran-ukuran fisik dari motor arus searah.

Kecepatan motor arus searah dipengaruhi oleh beberapa hal. Secara umum ukuran fisik motor arus searah dan catu daya akan menentukan besarnya kecepatan putar pada motor arus searah. Dengan memperbesar tegangan catu daya akan berpengaruh pada kecepatan putaran, dengan mengubah polaritas akan dihasilkan arah putaran yang berlawanan.

Dalam berbagai penerapannya motor arus searah harus dapat diatur kecepatannya sedemikian rupa sehingga dihasilkan gerakan dengan arah putaran dan kecepatan yang dapat diatur. Untuk mengatur kecepatan motor arus searah dapat dilakukan dengan beberapa cara, 
yaitu mengatur ukuran fisik motor arus searah, rangkaian pembagi tegangan dan arus dan menggunakan mikrokontroler.

Untuk menambah kecepatan motor arus searah dapat dilakukan dengan memperbesar potensial catu daya yang akan memperbesar flux medan magnet dan menambah kumparan. Sedangkan untuk mengatur arah putaran dilakukan dengan mengubah polaritas pada titik catu daya. Tindakan tersebut tidak mudah dapat dilakukan, karena ukuran badan magnet, jumlah lilitan pada kumparan dan catu daya harus diatur sedemikan rupa sehingga menimbulkan medan listrik dan medan magnet yang dapat dikonversi menjadi putaran pada rotor. Sehingga untuk mengatur motor dengan kecepatan tertentu sulit dilakukan, karena harus mengatur besaran tertentu yang sulit dikonversi menjadi besaran gaya dan kecepatan.

Cara lain yang dapat digunakan untuk mengatur kecepatan motor arus searah adalah dengan membuat rangkaian elektronik. Fungsi utama rangkaian tersebut adalah mengatur catu daya berupa tegangan dan arus yang masuk dengan menggunakan sebuah Resistor Variabel yang dapat diputar ke kiri dan ke kanan untuk memperbesar dan memperkecil kecepatan putaran. Kelemahan rangkaian ini adalah besaran kecepatan diatur secara manual, tergantung besar kecilnya putaran pada resitor variabel. Besarnya kecepatan tidak bisa ditentukan dengan pasti berdasar besaran kecepatan, yaitu kecepatan sudut.

Dengan menggunakan mikrokontroler untuk mengatur kecepatan motor arus searah akan lebih fleksibel dan lebih akurat besarnya kecepatan yang dihasilkan. Kecepatan motor arus searah dapat diatur berdasar nilai-nilai besaran tertentu sehingga dapat diatur besarnya kecepatan dan arah putaran tanpa mengubah ukuran motor secara fisik.

\section{TINJAUAN PUSTAKA}

K. Priyanka, A. Mariyammal meneliti kecepatan motor DC menggunakan metode PWM ( Pulse Width Modulation) dan mikrokontroler AT 89S51 sebagai perangkat system kendali. Sebuah motor DC dapat dikendalikan kecepatannya dengan menggunakan sinyal PWM sebagai sinyal masukan pada mikrokontroler. PWM adalah sebuah mertode yang digunakan untuk mengatur kecepatan motor dengan menggunakan pulsa sebagai sinyal yang dijadikan referensi dalam mengatur kecepatan. Fungsi sinyal PWM adalah sebagai trigger pada driver motor DC untuk memberikan daya kepada motor DC.

Driver motor yang digunakan adalah IC L293 D. Sensor infra red digunakan sebagai sensor kecepatan motor dan IC 555 digunakan sebagai counter untuk menghitung besaran kecepatan dalam satuan putaran per menit ( RPM ). Kecepatan motor ditunjukkan pada layar LCD. Agar kecepatan motor stabil pada harga tertentu diperlukan pulsa yang stabil.[1]

Hakan Acikgoz dalam penelitiannya yang berjudul Speed Control of DC Motor Using Interval Type-2 Fuzzy Logic mengatakan bahwa motor dc merupakan peralatan yang sering digunakan dalam berbagai macam implementasi dengan kecepatan dan arah putar yang berbeda-beda. Dengan berkembangnya teknologi semikonduktor pengaturan kecepatan motor dapat dilakukan dengan menggunakan mikrokontroler.

Dalam penelitiannya pengaturan kecepatan dilakukan menggunakan Simulink, sebuah model sistem kendali kecepatan motor dc menggunakan logika Fuzzy. Dengan model ini dapat diterapkan prinsip kerja pengaturan motor dc secara Proporsional (P) dam Integral (I).

Eddy Nurraharjo, Perkembangan teknologi digital secara umum menyebabkan teknologi sistem kendali berkembang sejalan dengan dengan perkembangan sistem digital. Perubahan Sistem Kendali analog menjadi sistemkendali digital meruapakan salah satu hal yang menjadi awal berkembangnya sistem kendali. Dengan berubahnya sistem kendali analog menjadi sistem kendali digital maka jenis perangkat yang digunakan juga berubah. Perancangan sebuah sistem kendali dengan menggunakan mikrokontroler terdiri 3 tahapan. Tahap pertama adalah 
merancang model sistem kendali. Pada tahap ini ditentukan semua parameter yang berhubungan, model sistem kendali, kebutuhan perangkat keras dan perangkat lunak. Tahap kedua adalah perancangan algorithma untuk menyelesaikanb masalah dalam sistem kendali. Pada tahap ini dibuat tahap demi tahap proses penyelesaian masalah sistem kendali secara rinci dan perancangan program. Tahap ketiga adalah implementasi dan pengujian sistem kendali. Pengujian yang dilakukan adalah dengan mencoba semua fasilitas yang tersedia dalam sistem kendali.[5]

\section{METODE PENELITIAN}

Metode yang akan digunakan dalam penelitian ini terdiri dari langkah-langkah sebagai berikut ;

\section{a. Studi Literatur}

Untuk memperoleh dasar teori berkaitan dengan pemrograman mikrokontroler, pemrograman $\mathrm{C}$ baik berasal dari jurnal, buku maupun informasi baku lainnya yang bersumber dari situs-situs di internet

b. Metode perancangan sistem

Berdasarkan hasil studi literatur, peneliti merancang sebuah sistem pengaturan kecepatan dengan menggunakan mikrokontroler berbasis Arduino UNO R3. Pada tahap ini direncanakan perangkat keras dan perangkat lunak yang digunakan untuk sistem pengaturan motor arus searah.

c. Metode perakitan atau pengujian

Rangkaian hasil perancangan dirakit dalam sebuah papan percobaan dan diberikan uji kelayakannya untuk mengetahui kinerja sistem. Dalam pengujian dilakukan pengukuran tegangan pada beberapa titik menggunakan voltmeter dan kecepatan putaran menggunakan sensor optocoupler sebagai tachometer ( RPM meter).

\section{HASIL DAN PEMBAHASAN}

\section{a. Rancangan Sistem Pengaturan Kecepatan Motor}

Untuk mengatur kecepatan putaran sebuah motor arus searah dapat dapat dilakukan dengan merekayasa perangkat keras dengan cara membuat sebuah rangkaian elektronik yang dapat mengatur kecepatan putaran sebuah motor arus searah. Kecepatan putaran motor dilakukan dengan mengatur nilai hambatan sebuah resisttor variable yang merupakan salah satu komponen dalam rangkaian. Perubahan nilai hambatan dilakukan dengan memutar resisttor variable sehingga menghasilkan putaran dengan kecepatan tertentu. Kelemahan cara ini adalah kecepatn dilakukan secara manual, sehingga kecepatan tidak dapat ditentukan seacara akurat.

Cara lain untuk mengatur kecepatan motor adalah menggunakan metode Pulse Width Modulation ( $P W M$ ). Motor arus searah berputar berdasarkan pulsa-pulsa yang dihasilkan dai sebuah generator pulsa. Kecepatan motor tergantung pada frekuensi pulsa yang berasal dari generator pulsa.

Sistem pengaturan kecepatan motor arus searah merupakan sebuah sistem pengaturan yang berfungsi mengatur kecepatan motor arus searah menggunakan perangkat lunak. Dengan menggunakan sebuah mikrokontroler yang telah diprogram sedemikian rupa sehingga dapat mengatur kecepatan motor berdasar algorithma yang diterapkan pada program. Untuk mengatur kecepatan motor dilakukan dengan memberikan sebuah nilai tertentu pada sebuah variabel tertentu dalam program. Dengan demikian besarnya kecepatan motor ditentukan oleh nilai variabel yang berupa sebuah bilangan integer. 
Motor arus searah merupakan peralatan elektronik yang bekerja secara analog, sedangkan mikrokontroler merupakan perangkat yang bekerja dengan sistem digital. Agar supaya motor arus searah dapat dikendalikan menggunakan mikrokontroler maka diperlukan sebuah rangkaian yang berfungsi sebagai antar muka motor dengan mikrokontroler. Rangkaian tersebut menggunakan sebuah IC dan disebut driver motor DC atau motor arus searah.

Salah satu mikrokontroler yang digunakan adalah Arduino. Bahasa pemrograman yang digunakan dalam Arduino adalah bahasa C. Arduino dilengkapi dengan fitur-fitur yang dpat digunakan sebagai sistem kendali. Salah satu syarat sistem kendali adalah adanya modul I/O yang berfungsi sebagai media komunikasi antar muka suatu peralatan dengan peralatan lain. Modul I/O berisi A/D converter dan D/A converter yang berfungsi sebagai pengubah sinyal analog menajadi sinyal digital. Sinyal yang berasal dari piranti yang menghasilkan besaran analog seperti tegangan dan arus tidak dapat diolah oleh mikrokontroler Untuk mengubah sinyal analog menjadi sinyal digital atau sebaliknya Arduino dilengkapi dengan A/D converter dan D/A converter. Blok diagram sistem pengaturan kecepatan motor arus searah menggunakan arduino dapat dilihat pada gambar 1.

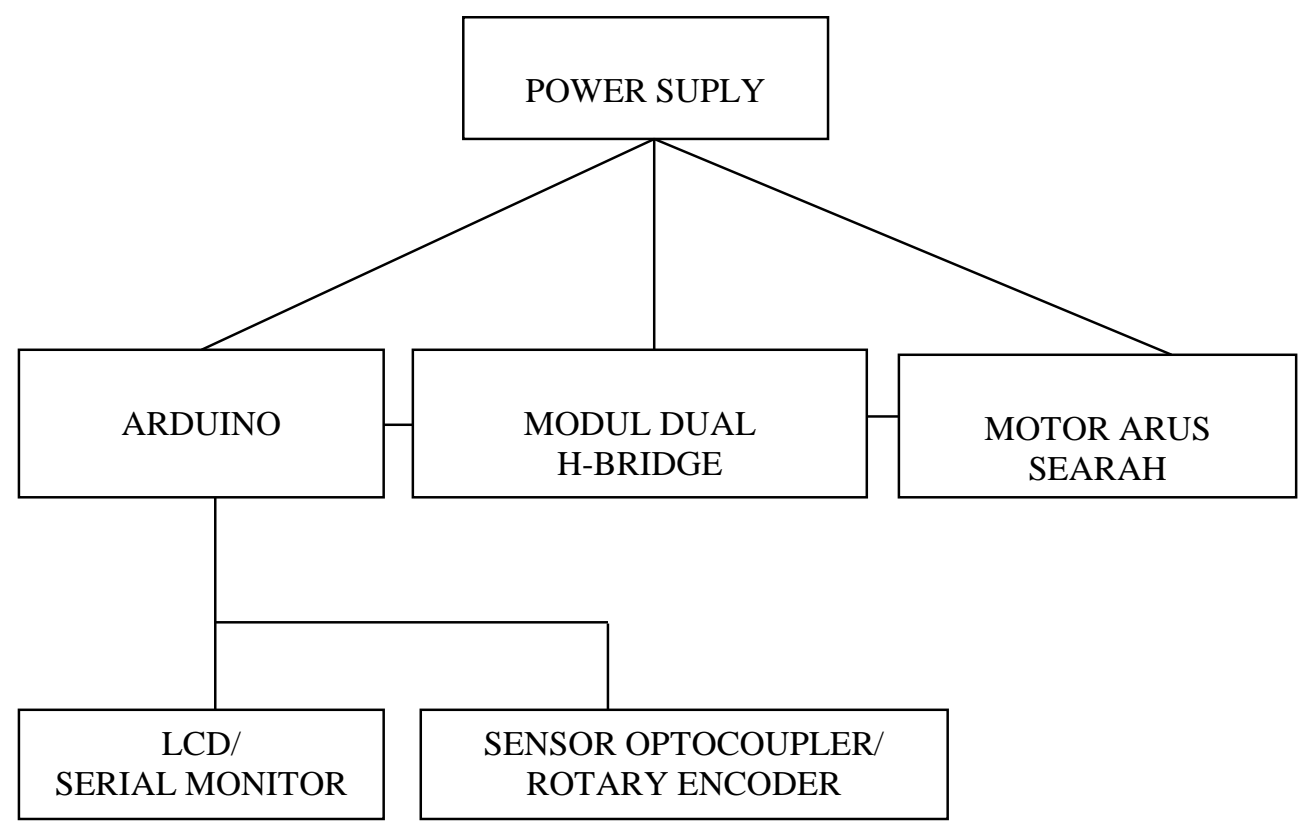

Gambar 1. Blok Diagram Sistem Pengaturan Kecepatan Motor Arus Searah

\section{b. Pengaturan Arah Putaran}

Cara kerja sistem pengaturan kecepatan motor arus searah dapat dilihat pada diagram alir gambar 2. Masukann sistem pengaturan adalah berupa sinyal digital yang berasal dari mikrokontroler. Sinyal tersebut dijadikan sebagai triger bagi modul Dual H-Bridge untuk memberikan daya kepada motor untuk bergerak dengan kecepatan tertentu.

Proses utama yang terjadi dalam sistem kendali adalah mengatur kondisi pin-pin digital yang akan dijadikan sebagai triger untuk memicu motor arus searah. Pada penelitian ini yang digunakan sebagai triger adalah pin Digital 3,4,5 dan 6 ( D3, D4, D5, D6) pada Arduino. Karena yang digunakan adalah pin digital maka nilai yang dihasilkan sebagai hasil dari proses adalah berupa besaran digital, yaitu "HIGH" dan "LOW". Dalam keadaan HIGH tegangan pada titik pin adalah \pm 5 volt, sedangkan pada keadaan LOW tegangan \pm 2 volt. 


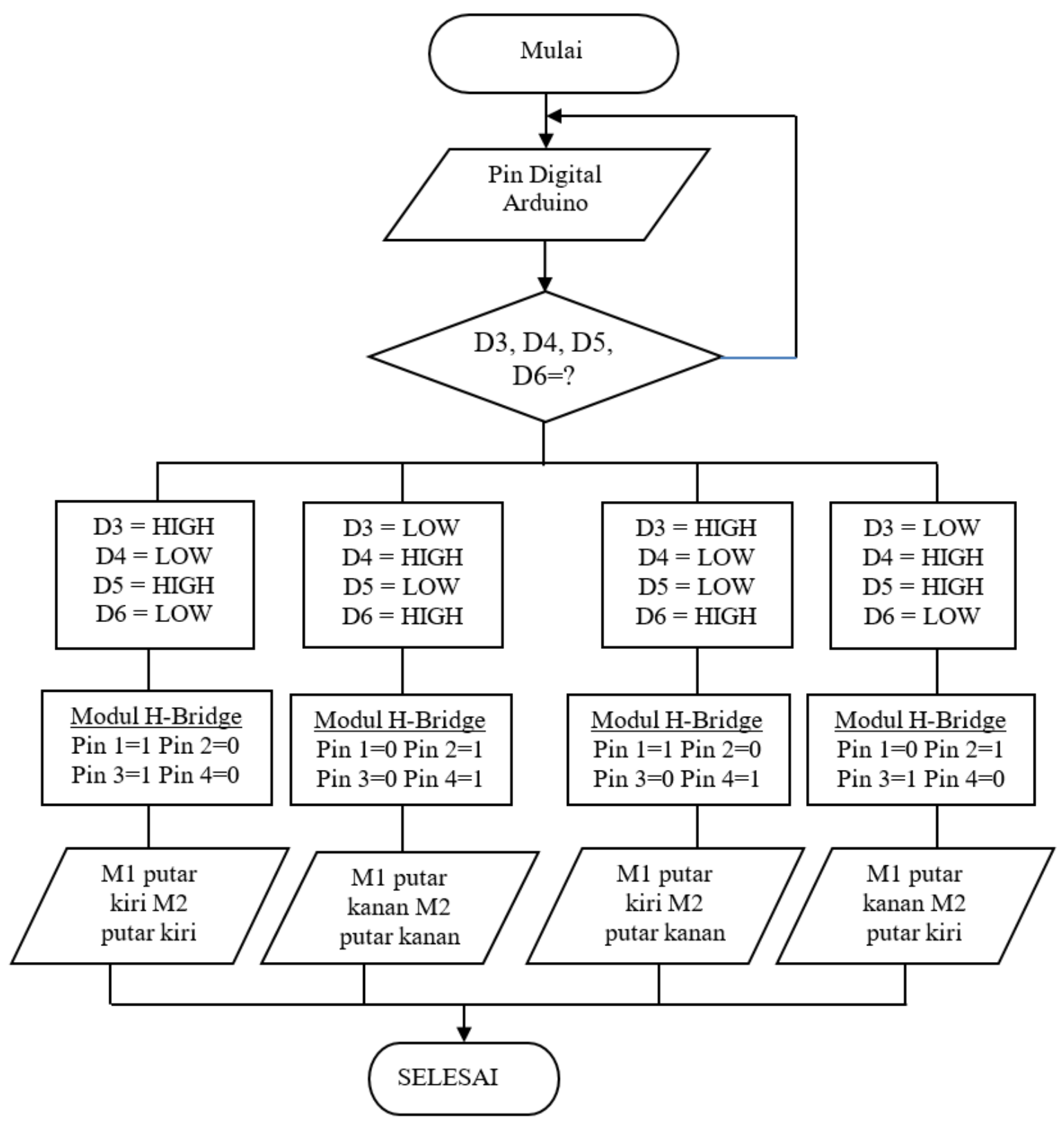

Gambar 3 Diagram Alir Sistem Pengaturan

Sinyal yang berasal dari pin digital arduino masuk ke driver motor DC untuk diproses menjadi daya yang dapat menggerakkan motor DC. Modul Dual H-Bridge adalah sebuah rangkaian elektronik yang berfungsi mengubah besaran digital menjadi besaran analog. Sinyal yang besasal dari pin digital arduino dijasikan sebagai triger untuk menggerakkan motor DC. Modul tersebut mempunyai 4 (empat) buah pin sebagai masukan dan empat buah keluaran. Pin-pin masukan digunakan untuk mengatur gerakan 2 buah motor DC. Sepasang motor DC dihubungkan dengan 2 buah keluaran pada driver motor DC yang berfungsi sebagai catu daya positip dan negatip. Polaritas catu daya tergantung pada sinyal masukan dari arduino.

Dari gambar 2 terdapat 4 jenis proses yang terjadi berdasar kemungkinan masukan masukan pada pin digital arduino. Masing-masing proses menghasilkan keluaran berupa sinyal digital yang bernilai HIGH dan LOW yang dijadikan sebagai pemicu untuk putaran motor arus searah. Hasil dari proses ditunjukkan pada 2 buah motor arus searah. Berdasar masukan dari pin digital arduino, kemungkinan hasil proses yang terjadi adalah sebagai berikut : 
Tabel 1 Tabel Kemungkinan gerakan motor

\begin{tabular}{|c|c|c|c|c|c|}
\hline PIN D3 & PIN D4 & PIN D5 & PIN D6 & MOTOR 1 & MOTOR 2 \\
\hline 0 & 0 & 0 & 0 & berhenti & Berhenti \\
\hline 0 & 0 & 0 & 1 & berhenti & Putar kanan \\
\hline 0 & 0 & 1 & 0 & berhenti & Putar kiri \\
\hline 0 & 1 & 0 & 0 & Putar kanan & Berhenti \\
\hline 1 & 0 & 0 & 0 & Putar kiri & Berhenti \\
\hline 0 & 1 & 0 & 1 & Putar kanan & Putar kanan \\
\hline 1 & 0 & 1 & 0 & Putar kiri & Putar kiri \\
\hline 0 & 1 & 1 & 0 & Putar kanan & Putar kiri \\
\hline 1 & 0 & 0 & 1 & Putar kiri & Putar kanan \\
\hline 1 & 1 & 1 & 1 & berhenti & Berhenti \\
\hline
\end{tabular}

\section{c. Pengaturan Kecepatan Motor}

Pada bab sebelumnya telah dibahas cara kerja sistem pengaturan arah putaran motor arus searah. Dengan mengatur polaritas catu daya pada motor arus searah akan dihasilkan dua arah putaran yang berbeda, yaitu putaran searah jarum jam dan berlawan arah jarum jam.

Proses yang digambarkan diagram alir pada gambar 4 hanya mengendalikan arah putaran saja. Sedangkan kecepatan motor arus searah tergantung pada sinyal triger dari mikrokontroler. Sinyal yang dihasilkan dari mikrokontroler adalah berupa sinyal digital yang berupa pulsa digital dengan frekuensi yang dapat diatur melalui sebuah program. Salah satu kemampuan dari mikrokontroler adalah kemampuan sebagai alat yang dapat berfungsi sebagai pengatur peralatan lain sesuai dengan yang dikehendaki.

Cara kerja sistem pengaturan kecepatan motor searah menyerupai metode PWM. Dalam sistem pengaturan kecepatan motor menggunakan mikrokontroler sebagai sumber sinyal adalah mikrokontroler yang dapat menghasilkan pulsa-pulsa digital dengan frekuensi yang dapat diatur dengan program. Sedangkan dalam metode PWM sinyal diperoleh dari rangkaian elektronik yag berfungsi sebagai generator sinyal.

Pengaturan kecepatan motor arus searah dilakukan dengan mengatur delay time pada program yang dibuat dengan arduino. Sebuah motor arus searah akan berputar bila ada catu daya yang bekerja pada kumparannya. Catu daya yang diberikan pada motor arus searah diatur oleh sinyal yang berasal dari pin digital arduino. Frekuensi sinyal yang dihasilkan oleh arduino diatur melalui nilai delay time. Semakin tinggi nilai delay time frekuensi semakin kecil demikian sebaliknya dan semakin kecil frekuensi sinyal. Akibatnya respon yang diterima oleh driver motor semakin cepat, dan motor akan berputar lebih cepat. Sehingga dapat dikatakan bahwa motor akan berputar berdasarkan frekuensi pulsa-pulsa digital yang dihasilkan oleh arduino, dan frekuensi pulsa diatur melalui program Bila nilai delay time kondisi HIGH (T1) dan LOW (T2) berbeda, maka kecepatan motor akan berubah. Jika selisih antara T1 dan T2 akan mempengaruhi kecepatan motor arus searah. Kemungkian yang terjadi dengan adanya pengaturan nilai delay time adalah sebagai berikut:

a. Jika T11 = T12, pin D3=D5=HIGH, D4=D6=LOW maka kecepatan M1= M2, dan arah putaran yang sama sarah jarum jam

b. Jika T21 = T22, pin D4=D6=HIGH, D3=D5=LOW maka kecepatan M1= M2, dan arah putaran yang sama berlawanan jarum jam

c. Jika T11 > T12, pin D3=D5=HIGH, D4=D6=LOW maka kecepatan M1> M2, dan arah putaran M1 dan M2 berlawanan

d. Jika T12 < T22, pin D3=D5=HIGH, D4=D6=LOW maka kecepatan M1< M2, dan arah putaran M1 dan M2 berlawanan 
Besarnya kecepatan tergantung pada selisih antara T11 dan T12 ( T11 - T12 ), T21 dan T22 ( T21-T22). Semakin besar selisih antara kondisi HIGH dan LOW, maka kecepatan putaran semakin besar dan sebaliknya. Sedangkan arah mau dan mundur ditentukan oleh nilai pin digital D3, D4, D5 dan D6 Arduin

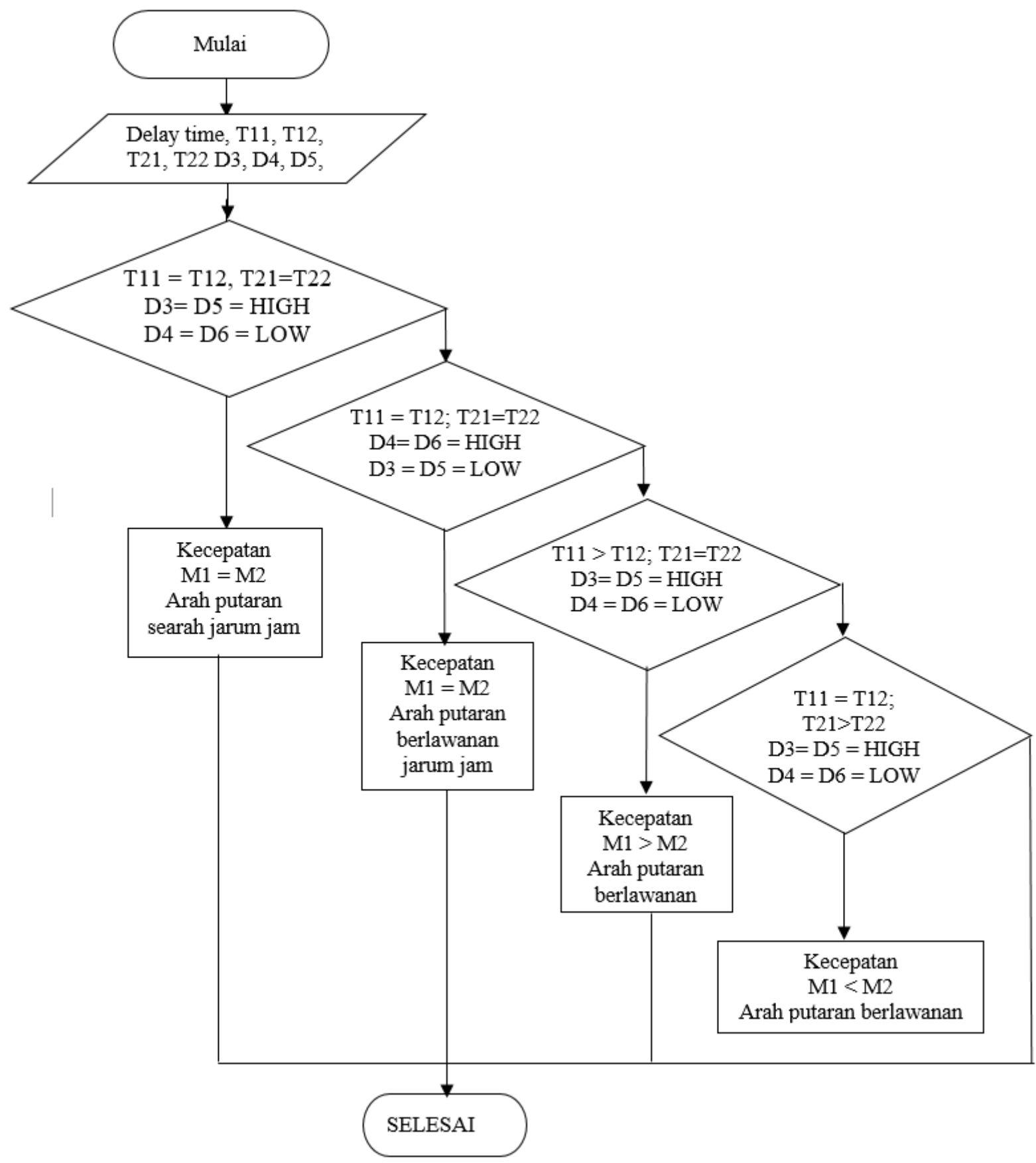

Gambar 4. Diagram Alir Sistem Pengatur Kecepatan Motor

\section{d. Hasil Pengukuran Tegangan}

Hasil Pengukuran Tegangan pada titik-titik masukan dan keluaran pada beberapa titik dapat dilihat pada tabel 2 : 
Tabel 2 Hasil Pengukuran Tegangan

\begin{tabular}{|l|l|c|c|}
\hline No & Titik Pengukuran & $\begin{array}{c}\text { Tegangan Saat HIGH } \\
(\text { Volt })\end{array}$ & $\begin{array}{c}\text { Tegangan Saat LOW } \\
\text { ( Volt) }\end{array}$ \\
\hline 1 & Vcc & 5,59 & 5,59 \\
\hline 2 & D3 & 4,93 & 1,89 \\
\hline 3 & D4 & 4,93 & 1,91 \\
\hline 4 & D5 & 4,92 & 1,92 \\
\hline 5 & D6 & 4,93 & 1,91 \\
\hline 6 & Motor -1 & 3,41 & 0 \\
\hline 7 & Motor -2 & 3,41 & 0 \\
\hline
\end{tabular}

Dari data hasil pengukuran terlihat bahwa tegangan pada pin D3, D4, D5 dan D6 yang terukur sebesar \pm 5 volt dapat digunakan sebagai sinyal masukan pada driver motor DC untuk menggerakkan motor DC. Sedangkan tegangan pada motor arus searah merupakan tegangan yang dihasilkan oleh modul dual H-bridge.

Arduino sebagai mikrokontroler akan berfungsi sebagai pusat kendali gerakan. Program utama yang diupload pada arduino berisi perintah untuk menggerakkan motor DC melalui sinyal digital yang dikeluarkan melalui pin D3, D4, D5 dan D6. Dengan kombinasi nilai-nilai pin D3, D4, D5 dan D6 akan dihasilkan gerakan robot mobil sesuai dengan rancangan.

Parameter yang mempengaruhi kecepatan motor DC adalah nilai delay time. Dalam program terdapat 4(tiga) nilai delay time yang berfungsi mengatur kecepatan motor DC yang berakibat berubahnya kecepatan robot mobil. Fungsi dari delay time adalah mengatur waktu kondisi HIGH dan LOW pin D3, D2, D5 dan D6. Kemungkinan yang terjadi dengan berubahnya nilai delay time adalah sebagai berikut :

1) Jika delay time untuk kodisi HIGH pin D3 dan D5 sama dengan delay time kondisi LOW maka Motor -1 dan Motor - 2 akan bergerak searah jarum jam dengan kecepatan yang sama.

2) Jika delay time untuk kodisi HIGH pin D3 dan D5 tidak sama dengan delay time kondisi LOW maka Motor -1 dan Motor - 2 akan bergerak searah jarum jam dengan kecepatan yang berbeda

\section{e. Hasil Pengukuran Kecepatan Motor}

Alat yang digunakan untuk mengukur kecepatan adalah modul sensor optocoupler. Nilai yang ditampilkan di LCD dan serial monitor adalah jumlah putaran per menit ( RPM). Percobaan yang dilakukan untuk mengatur kecepatan adalah dengan cara mengubah delay time kondisi HIGH dan LOW untuk pin D3, D4, D5 dan D6. Delay time adalah sebuah function dalam program yang berfungsi mengatur waktu suatu proses dalam satuan milisecon. Contoh sketch untuk mengatur kecepatan adalah sebagai berikut :

1) digitalWrite(D3, HIGH);

2) digitalWrite(D5, HIGH);

3) delay(5);

4) digitalWrite(D3, LOW);

5) digitalWrite(D5, LOW);

6) delay(15);

\section{Keterangan :}

a. Baris 1 dan 2 merupakan sketch untuk memberikan kondisi HIGH pada pin D3 dan pin D5

b. Baris 3 adalah sketch untuk mengatur waktu kondisi HIGH pin D3 dan pin D5 selama 5 milisecon.

c. Baris 4 dan 5 merupakan sketch untuk memberikan kondisi LOW pada pin D3 dan pin D5 
d. Baris 6 adalah sketch untuk mengatur kondisi LOW pin D3 dan pin D5 selama 5 milisecon.

Hasil yang diperoleh dalam percobaan adalah sebagai berikut :

a. Jika delay time HIGH sama dengan delay time LOW maka akan diperoleh kecepatan maksimal. Besarnya kecepatan hanya tergantung pada catu daya yang diberikan pada modul Dual H-bridge.

b. Jika delay time HIGH lebih besar dari pada delay time LOW maka akan diperoleh kecepatan maksimal. Besarnya kecepatan hanya tergantung pada catu daya yang diberikan pada modul Dual H-bridge.

c. Jika delay time HIGH lebih kecil dari pada delay time LOW maka akan kecepatan akan berkurang berbanding lurus dengan selisih delay time. Besarnya kecepatan tidak lagi tergantung pada catu daya pada modul Dual-H bridge

d. Jika nilai delay time lebih dari 25 akan diperoleh kecepatan motor maksimum. Selisih delay time HIGH dan LOW tidak berpengaruh pada kecepatan motor.

\section{KESIMPULAN}

Dari hasil perancangan dan pengujian sistem kendali dapat disimpulkan hal-hal sebagai berikut:

a. Kecepatan motor arus searah dapat dilakukan menggunakan mikrokontroler dengan cara merekayasa program sedemikian rupa sehingga mikrokontroler menghasilkan pulsa digital yang dapat diatur frekuensinya. Sinyal digital berfungsi sebagai sinyal triger untuk menggerakkan motor, sehingga frekuensi sinyal akan berpengaruh terhadap kecepatan motor.

b. Perubahan frekuensi sinyal dilakukan dengan mengatur selisih delay time HIGH dan LOW pada pin yang digunakan sebagai masukan modul Dual H-Bridge.

c. Semakin besar silisih perbedaan delay time kecepatan berputar motor semakin kecil

\section{SARAN}

Keterbatasan kualitas peralalatan yang digunakan menyebabkan hasil yang diperoleh kurang akurat. Sehingga untuk memperoleh hasil yang optimal dilakukan dengan menggunakan perlatan yang tingkat akurasinya lebih tinggi. Diantara peralatan yang perlu dilakukan perbaikan adalah alat ukur kecepatan dan sensor kecepatan yang lebih baik.

\section{DAFTAR PUSTAKA}

[1] Austin Hughes, 2016, Electric Motors and Drives Fundamentals, Types and Applications, Third edition, Elsevier Ltd. All rights reserved, ISBN-13: 978-0-75064718-2 ISBN-10: 0-7506-4718-3

[2] Eddy Nuraharjo, 2013, "Sistem Kendali Mobil Robot dengan Menggunakan Mikrokontroler ATMEGA 89S52”,

[3] Endra Pitowarno, 2013, Robotika Desain, Kontrol, dan Kecerdasan Buatan, Andi, Yogyakarta

[4] K. Priyanka, 2018, A. Mariyammal, DC Motor Speed Control Using PWM, Department of Electrical and Communication Engineering, Vivekanandha College of Engineering for Women(Autonomous), Tiruchengode

[5] Hakan Acikgoz, 2018, Speed Control of DC Motor Using Interval Type-2 Fuzzy Logic Controller, International Journal of Intelligent Systems and Applications in Engineering ISSN:2147-6799, www.ijisae.org 
[6] [6] T.K. Sethuramalingam and M. Karthighairasan, Automatic Gas Valve Control System using Arduino Hardware, Bonfring International Journal of Power Systems and Integrated Circuits, Vol. 2, No. 3, September 2012

[7] Zuly Budiarso, 2015, "Rancang Bangun Sistem Kendali Digital Electrical Stimulator Berbasis Arduino UNO R3".

[8] Zuly Budiarso, 2016, "Sistem Kendali Generator Sinyal XR-2206 Berbasis Arduino UNO R3

[9] https://www.arduino.cc/

[10] https://www.alldatasheet.com 